\title{
МОРФОЛОГІЧНІ СПОСОБИ ТЕРМІНОТВОРЕННЯ (НА МАТЕРІАЛІ СУЧАСНОЇ УКРАЇНСЬКОЇ ФІТОМЕЛІОРАТИВНОЇ ТЕРМІНОЛОГІї)
}

\author{
ТЕТЯНА ПЕТРОВА \\ Харківський національний аграрний університет імені В. В. Докучаєва, \\ Харків - Україна \\ t-petrova@ukr.net \\ MORFOLOGICZNE SPOSOBY TERMINOTWÓRSTWA \\ (NA MATERIALE WSPÓŁCZESNEJ UKRAIŃSKIEJ \\ TERMINOLOGII FITOMELIORACYJNEJ) \\ TETIANA PETROWA \\ Charkowski Narodowy Uniwersytet Rolniczy imienia W. W. Dokuczajewa, \\ Charków — Ukraina
}

\begin{abstract}
STRESZCZENIE. W pracy przeanalizowano morfologiczne sposoby tworzenia terminów fitomelioracji: za pomocą prefiksów, sufiksów, prefiksów i sufiksów, wyrazów złożonych. Ustalono, że wyrazy złożone oraz tworzenie leksemów za pomocą sufiksów stanowią najważniejszy sposób rozbudowy ukraińskiej fitomelioracyjnej terminologii. Wyjaśniono, iż badany system terminologiczny w większym stopniu wzbogacił się dzięki zapożyczonym morfemom rdzennym, w mniejszym zaś dzięki morfemom słowotwórczym, m.in. prefiksom i sufiksom. Stwierdzono, iż rodzime morfemy mają większe możliwości derywacyjne do tworzenia terminów fitomelioracji.
\end{abstract}

\section{MORPHOLOGICAL METHODS OF TERM FORMATION (ON THE MATERIAL OF MODERN UKRAINIAN PHYTOMELIORATIVE TERMINOLOGY)}

\author{
TETIANA PETROVA \\ Kharkiv V. V. Dokuchayev National Agrarian University, Kharkiv — Ukraine
}

\begin{abstract}
Such morphological methods of the form phytomeliorative terms as those with a prefix, suffix and a stem composing one have been analyzed in the article. It has been ascertained that the important methods of modern Ukrainian phytomeliorative terminology development are these with a suffix and a stem composing one. It has been found out that the researched term system has been enriched with foreign languages root morphs largely and with prefixoids and suffixoids - to a less extent. It has been defined that original morphemes have more derivation possibilities to form phytomeliorative terminology.
\end{abstract}

\section{3}

начне збагачення термінологічного апарату фітомеліорації відбувається завдяки використанню наявних у системі української мови морфемних ресурсів (кореневих і афіксальних). Розвиток терміносистеми шляхом морфологічного термінотворення полягає в поєднанні афіксальних морфем з твірною основою за певними словотвірними моделями національної мови. Творення термінів фітомеліорації морфологічним способом визначаємо за такими його типами: 1) префіксальне термінотворення; 2) суфіксальне термінотворення; 3) префіксально-суфіксальне термінотворення; 4) основоскладання. 
Особливості термінотворення, на відміну від загальномовного словотворення, полягають у використанні обмеженої кількості моделей, що є головним чинником системної організації термінології 1.

Морфологічне термінотворення - найпоширеніший спосіб творення синтетичних термінів або компонентів (іменників, прикметників) аналітичних термінів. Поширеність цього способу пояснюють його продуктивністю, оскільки в термінах, утворених морфологічним способом, закладені основи структурного систематизування, тобто „на позначення однотипних технічних понять використовуються однотипні способи словотвору”. „При цьому суфікси та префікси $[\ldots]$ виявляються зручними для побудови термінів, запозичуються, як правило, із загального морфологічного фонду. Проте деякі афікси можуть зустрічатися лише у фахових термінах, а в загальнолітературній лексиці можуть бути взагалі відсутні. Окрім того, за деякими суфіксами закріплені певні термінологічні значення $[\ldots]^{\prime \prime 3}$.

Фіксуємо незначну кількість префіксальних формантів, що беруть участь у творенні фітомеліоративних термінів. Переважно це питомі префікси, що приєднуються однаковою мірою і до власне українських, $\mathrm{i}$ до чужомовних основ. Префіксальне термінотворення - це спосіб творення терміноодиниць за допомогою префіксів. Напр., префікс $c y$-, що вказує на об'єднання чогось на певній основі, може приєднуватися до питомої твірної основи іменника й утворювати терміни на позначення видів грунту чи лісу: субір, субучина, сугруд, судіброва, сурамінь.

В аналізований лексиці прикметникові терміноодиниці на позначення ознаки чи властивості, що вказують на заперечення дії, утворюються приєднанням компонента проти- як до питомих, так і до чужомовних ад'єктивних твірних основ, напр.: протиабразійний захист берегів, протиерозійна споруда, протилавинна споруда. Префікс без-, сполучаючись із твірними прикметниковими основами (відвальний, хлорофільний), утворює терміноодиниці, що $\epsilon$ складниками термінів-словосполучень і вказують на відсутність ознаки або властивості в позначуваному об'єкті чи процесі: безвідвальний обробіток трунту, безхлорофільні рослини.

Для творення процесових іменників фітомеліоративна термінологія використовує також чужомовні префіксальні морфеми. Напр., префікс де- (лат. $d e-$ ) має кілька значень: 1) відокремлення, видалення, усунення, відміна, скасування; 2) рух униз, падіння, зниження (демутація - зміна рослинності чи тваринного світу після антропогенного втручання й порушення чи дигресії, що і призводить до відновлення угруповань попереднього складу; декальциинація трунту утрата гумусовим шаром грунту кальцію за рахунок процесу його вилуження в нижчі шари). Формант $\boldsymbol{i \boldsymbol { \mu } -}$ (лат. in-) позначає процес проникнення чогось у щось (інфільтрація - процес проникнення води вниз по тріщинах, ходах землерийок, пустотах у грунті, а також по капілярах і порах грунту). Префіксальний формант ко- (лат. со-) означає об'єднання, спільність, сумісність (коеволюиія еволюційно-біологічна взаємодія видів без обміну генетичною інформацією в процесі їхнього спільного розвитку в біоценозі). Отже, питомі префіксальні

${ }^{1}$ Л. О. С им онен ко, Формування украӥнської біологічної термінологї̈, Київ 1991, с. 91.

${ }^{2}$ Н. І. Шило, Структурні типи украӥнських технічних термінів (на матеріалі лісової та деревнообробної термінологіi), [в:] Питання словотвору, Київ 1979, с. 29.

${ }_{3}^{3}$ С. Дорошен но, Особливості афіксаиії при термінотворенні (на прикладі термінології нафто-газової промисловості), [в:] „Вісн. Нац. ун-ту «Львівська політехніка». Сер. Проблеми української термінології”, відп. ред. Б. Р и ц ар, Львів 2010, № 675, с. 10. 
Морфологічні способи термінотворення

(на матеріалі сучасної украӥнської фітомеліоративної термінологї)

афікси активно застосовують для творення одиниць на позначення видів грунту чи лісу, ознаки чи властивості предмета; чужомовні префікси - переважно для творення термінів, що позначають процес.

Суфіксальне термінотворення - широко використовуваний способом розбудови термінології фітомеліорації. Для творення термінів-іменників найчастіше застосовують суфіксальні морфеми -енн-, -нн- на позначення процесу або дії. Названі суфікси приєднують здебільшого до питомих дієслівних основ, напр.: вапнування, валкування, вивітрювання, вирубування, глинування, заліснення, кротування, лункування, мульчування, піскування, снігування, щілювання. Особливістю цих одиниць є те, що окремі 3 них установлюють мотиваційні зв'язки з дієсловами, зафіксованими в загальномовних словниках (вапнувати, валкувати, мульчувати). Для інших похідних термінів властивою, очевидно, є черезкрокова деривація, оскільки в узусі відсутні дієслівні твірні бази (кротування, піскування, розгіпсування, розсолонцюювання, снігування). Відсутність дієслівної твірної бази дає змогу також кваліфікувати похідні розгіпсування, розсолонциювання як конфіксальні одиниці. Зауважмо, що формант -нн- може сполучатися із запозиченими основами, що засвідчує високий рівень засвоєння чужомовних кореневих морфів, а також їхнє адаптування до словотвірних зразків національної мови, напр.: евтрофування, компостування, транспірування.

Запозичені фітомеліоративні терміни, що позначають галузь господарства, спосіб, вид або метод (вегетація, інтродукція, сидерація і т. ін.), непохідні, але членовані, оскільки під дією словотвірних закономірностей сучасної української мови, пристосовуючись до дериваційного рівня адаптації, вони вступають у мотиваційні зв'язки зі спільнокореневими словами. Унаслідок у морфемній будові терміноодиниць вичленовуємо чужомовні кореневі морфи й суфікс -ij- 3 процесуальним значенням.

Для творення термінів-іменників на позначення виду рослин використовують запозичений суфікс -тор, що сполучається з дієслівною чужомовною основою. Напр., едифікатор - вид рослин у рослинному співтоваристві, що відіграє важливу роль у формуванні структури екосистеми.

Терміни-іменники на позначення кущових, деревних порід утворюють поєднанням питомої префіксальної основи дієслова й нульового суфікса. Зокрема, від дієслова підганяти утворюється іменник підгін (“суукупність дерев та чагарників, уведених у лісові захисні насадження для прискорення росту у висоту й поліпшення форми стовбура головних порід"4), від підростати nidpicm (“'деревні рослини природного походження висотою до 1/4 частини деревного пологу $[. .$.$] "5), від поростати — nopicm (“молоді пагони, що з' являються зі$ сплячих або придаткових бруньок на пеньках або коренях дерев і чагарників"6). Безсуфіксний тип термінотворення, продукує незначну кількість термінів (за підрахунками — це 32 одиниці), проте вони формують поняттєве ядро лісової меліорації, що є підгалуззю фітомеліорації. Словотвірний потенціал питомих морфем забезпечує прозору мотивацію й поняттєву однозначність.

Терміни на позначення певної ознаки чи властивості утворюють від прикметникової основи додаванням суфікса -icmb: гігроскопічність, еродованість, ксероморфність, лісистість, маргінальність, парцелярність,

${ }^{4}$ Г. Б. Гладун, Лісові меліорації агроландиафтів: словник-довідник основних термінів та визначень, Харків 2003, с. 113.

${ }^{5}$ Там само, с. 114.

${ }^{6}$ Г. Б. Гладун, Лісові меліорачії: термінологічний словник, Харків 2008, с. 117. 
рясність, фітонцидність, ярусність. Зазначена модель служить для творення термінів, головно, від чужомовних основ.

Галузеві терміни-прикметники на позначення ознаки чи властивості, пов’ язаної зі значенням твірної основи, утворені за такими зразками: 1) “чужомовна іменникова основа + -ичн-" (агроценоз - агроценотичний, біоченоз біоченотичний, культурфітоценоз - культурфітоценотичний, фітоценоз фітоценотичний); 2) "питома / чужомовна іменникова основа + -н- або -ов-" (грядовий рельєф, кучовий рельєф, куртинні лісові насадження). Як бачимо, за розглянутими моделями виникають терміноодиниці від чужомовної твірної основи. Більшість термінів, що позначає ознаку чи властивість предмета і є компонентами термінологічних словосполучень, виникає за допомогою суфікса -н-; 3) “питома дієслівна основа + -н-” (підгінна порода).

У фітомеліоративній термінології для творення прикметників (дієприкметників), що вказують на здатність предмета чи об’єкта бути підданим певній діiі, використовують запозичену твірну дієслівну основу й питомий суфікс -н- (девастовані землі, дефльовані землі, еродовані грунти, затерасовані схили, меліоровані землі, фітомеліоровані територіі) або питомі твірну дієслівну основу й суфікс -ен- (озеленені територіi). Терміни, що вказують на ознаку за певною дією чи функцією, утворюють додаванням до дієслівної основи суфікса -льн-, напр.: кольматувальні насадження.

Отже, суфіксальний спосіб є важливим чинником творення фітомеліоративних термінів. Питомі суфіксальні морфеми, приєднуючись переважно до чужомовних іменникових, а також дієслівних основ, утворюють терміни, що позначають різноманітні поняття фітомеліорації.

Префіксально-суфіксальне (комбіноване) термінотворення, або конфіксальний спосіб, що полягає в одночасному приєднанні префікса та суфікса як одного форманта, є одним 3 головних способів творення термінів різної частиномовної належності. Він має більше словотвірних можливостей для комбінування препозиційних та постпозиційних афіксів. За допомогою цього способу продукують компоненти аналітичних термінів. Напр., одиниці (прикметники), що вказують на властивості або особливості певних об'єктів фітомеліорації, утворюють за такими моделями:

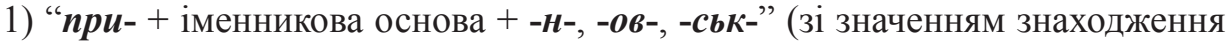
біля чогось), уживається для конкретизування видів лісових смуг і дерев: лісова прибалкова смуга, прибережна смуга, приканальна смуга, прикошарна смуга, прирічкові дерева, прируслова смуга, прифермерська смуга, прияружна смуга, пришляхова смуга;

2) “nid- + іменникова основа + -ов-”, використовують для утворення одиниць, які вказують на рівень вияву ознаки, що залежить від знаходження під чимось: піднаметова освітленість;

3) “без- + іменникова основа + -ев-", для творення термінів, що характеризують процес, який відбувається без використання чогось: безполицева оранка.

Модель “за- + дієслівна основа + -нн-" застосовують для творення термінів-іменників, що позначають дію чи процес, зокрема суцільне покриття чим-небудь схилів чи ярів (затерасування). Для продукування термінів на позначення дії чи процесу, крім дієслівних, залучають також іменникові основи, що поєднують 3 конфіксальними формантами, елементами яких є префікси

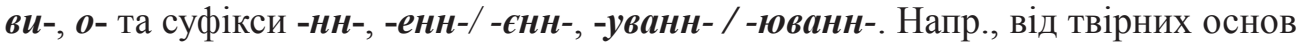
іменників глей (,1. Пластична глина (здебільшого гончарна) сизого, червоно- 
го та ін. кольорів. 2. Те саме, що мул 1"7), полог („степова рівнина, низовина, що полого, поступово спускається до берега річки" ${ }^{\text {) }}$, пустеля (,тип ландшафту, що характеризується рівнинною поверхнею, [...] відсутністю флори, фауни [...]”'), утворюються терміноодиниці - оглеєння / оглеювання трунту, виположення / виположування яру, опустелення / опустелювання. Наголосимо, що особливістю творення цієї групи термінів є використання твірних основ здебільшого загальновживаних лексем та одиниць суміжних галузей, що поєднуються з афіксальними морфемами й стають термінами фітомеліорації.

Мовний аналіз засвідчує, що префіксально-суфіксальне термінотворення $\epsilon$ способом творення таких спеціальних одиниць фітомеліорації, які вказують на властивості або особливості чого-небудь, а також процес чи дію. Поняттєве ядро досліджуваної галузі формують терміни, для творення яких використовують питомі афікси, що свідчить про свідому розбудову наукової терміносистеми відповідно до словотвірних закономірностей національної мови.

До сучасної української фітомеліоративної термінології належать складні терміни, утворені поєднанням основ. У науковій літературі на позначення цього морфологічного способу творення терміноодиниць дослідники використовують поняття “складання"10, “основоскладання"11, “композиція"12. "Основоскладання” науковці розуміють як „різновид морфологічного способу словотвору, що полягає у поєднанні кількох твірних основ в одному слові”"13, „поєднання кількох основ слів (основи й цілого слова) за допомогою інтерфіксів -о-, -е- або без них”"14. Композиція є „вищим ступенем абстрагування, об’єднуючи в одному слові кілька основ, що дає можливість точно характеризувати предмети, явища за кількома ознаками" 15 .

У цьомудослідженнізметоюуніфікування терміновживання використовуємо термін основоскладання, який розуміємо як спосіб творення термінологічних одиниць, що полягає в поєднанні твірних основ за допомогою сполучних голосних або без них. Основоскладання $\epsilon$ досить продуктивним способом творення термінів фітомеліорації. За структурно-морфологічними ознаками, способом і характером сполучення основ виділяємо такі типи найменувань:

1) складні терміни, першою частиною яких $є$ питома іменникова основа, а другою - питома дієслівна основа (болотоутворення, киснепродукування (рослин), лісорозведення, снігозатримання, травосіяння, яругоутворення).

7 Словник украӥнської мови, у 20 т., т. 1-6 (А - КВА́РТА), [в:] Електронний ресурс: http:// lcorp.ulif.org.ua/ExplS/ (10.08.2016).

${ }^{8}$ Словник української мови, в 11 томах, ред. колег. І. К. Біл оді д (голова), П. Й. Го рець ки й та ін., Київ 1970-1980, т. 7, с. 90.

${ }^{9}$ Г. Б. Гладун, Лісові меліорації: термінологічний словник, Харків 2008, с. 175.

${ }_{10}$ Т. О. Луко в е н ко, Складання як один зі способів термінотворення у галузі гомеопатії, [в:] „Термінологічний вісник”, зб. наук. праць, Київ 2013, вип. 2 (2), с. 28-31, [в:] Електронний ресурс: http://nbuv.gov.ua/UJRN/terv_2013_2(2)_6 (22.11.2016).

${ }_{11}$ Я. Мар' я н ко, Основоскладання як спосіб термінотворення в українській термінології дизайну, [в:] „Вісн. Нац. ун-ту «Львівська політехніка». Сер. Проблеми української термінологіі”, відп. ред. Б. Р иц а р, Львів 2012, № 733, с. 208-211.

${ }^{12} \mathrm{I}$. В. Ш м атко, Композиція як один із способів поповнення термінології бджільнитва, [в:] „Наукові записки Ніжинського державного університету імені Миколи Гоголя. Філологічні науки", відп. ред. проф. Г. В. Самойленко, Ніжин 2011, кн. 2, с. 52-55.

${ }^{13}$ Там само, с. 53.

14 М. Я. Плющ, Граматика украӥнської мови, у 2 ч., ч. 1. Морфеміка. Словотвір. Морфологія, підруч., Київ 2005, с. 31.

${ }^{15}$ Н. Ф. Клименко, Словоскладання. Абревіачія, [в:] Словотвір сучасної української мови, Київ 1979, с. 340. 
3 огляду на різний напрям мотивування ці одиниці можемо кваліфікувати як такі, що утворені шляхом “чистого" основоскладання (снігозатримання - затримання снігу) або основоскладання, ускладнене суфіксацією (снігозатримання затримати сніг);

2) складні терміни, першою частиною яких є питома іменникова основа, а другою - дієслівна основа з нульовим суфіксом (вітровал, сніговал);

3) складні терміни з обома питомими іменниковими основами (лісосад);

4) складні терміни, першою частиною яких є українська займенникова основа сам, а другою - питома або чужомовна дієслівна основа (самозаростання, самозрідження, самомеліорачія).

Серед фітомеліоративних лексем виявлясмо терміни-прикметники, утворені на основі терміносполучень з різними типами синтаксичного зв'язку. Зауважмо, що продукування таких одиниць супроводжується додаванням суфіксів зі значенням відносної ознаки чи властивості. Виділяємо такі моделі цього способу термінотворення:

1) “прикметникова основа + сполучний голосний $\boldsymbol{o}+$ іменникова основа + -ев-, - $\boldsymbol{-}$-" $з$ підрядним зв'язком компонентів твірної бази: лісонасіннєве районування, лісомеліоративні породи, лісорослинні умови, лісопатологічний нагляд; верхньонаметові, нижньонаметові, середньонаметові деревні рослини;

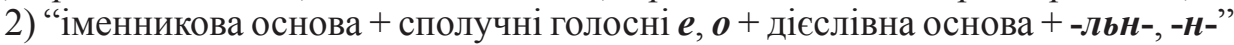
3 підрядним зв'язком компонентів твірної бази: берегозахисні, каналозахисні, садозахисні, схилозахисні, пасовищезахисні, піскозахисні, полезахисні лісові насадження; трунтозакріплювальні, піскозакріплювальні лісові насадження; вітрорегулювальні узлісся; стокорегулювальні смуги.

Мовний аналіз засвідчує, що основоскладання є одним зі способів творення фітомеліоративних термінів. Особливістю основоскладання спеціальних одиниць досліджуваної галузі є словотвірна активність окремих основ, що уточнюють ознаки чи функції інших компонентів. Унаслідок складання таких основ виникають терміни зі спеціалізованими значеннями, що вказують на специфіку фітомеліоративних заходів.

Значна частина сучасних фітомеліоративних термінів чужомовні за походженням. Особливістю таких одиниць $є$ те, що одні з них залишаються нечленованими, а інші, пристосовуючись до словотвірних закономірностей сучасної української мови і вступаючи в мотиваційні зв'язки з похідними, стають членованими. Складність морфемної будови окремих запозичених термінів полягає в тому, що інколи важко встановити статус препозиційних або постпозиційних елементів. У науковій літературі по-різному класифікують ці компоненти: афікси, напівафікси, афіксоїди, компоненти композита, радиксоїди, радикси (тобто корені), блоки, основи, морфемоїди і т. ін.

Єдиного погляду щодо статусу запозичених елементів у сучасному мовознавстві не існує. Так, у 80 -х роках XX ст. для розкриття їхнього статусу сформувалися два різні погляди: за Б. Бартковим - якісний (семантична і функційна характеристика) $)^{16}$; за К. Городенською - кількісний (кількісні підрахунки похідних із тим чи тим елементом) ${ }^{17}$. Однак сучасні лінгвістичні дослідження

${ }^{16}$ Б. И. Бартков, Продуктивность, частотность, валентность аффиксов и количественный словарь 130 словообразовательных формантов современного английского языка (научный стиль и литературная норма), [в:] Його ж, Особенности словообразования в научном стиле и литературной норме, Владивосток 1982, с. 17-56.

${ }^{17}$ К. Г. Городенсська, Префікси і префіксоїди в украйнській мові, [в:] „Мовознавство”, 1986, № 1, с. 36-41. 
Морфологічні способи термінотворення

(на матеріалі сучасної украӥнської фітомеліоративної термінологї)

засвідчують, що головні характеристики в основі вказаних підходів не повною мірою враховують важливі властивості чужомовних елементів. У нашій роботі беремо до уваги запропоновану Н. Кобзар трирівневу класифікацію морфем, за якою „на дихотомічній осі ‘афікс - корінь' можна виділити клас перехідних одиниць - кореневих за походженням морфем, які частково десемантизувалися й функціонально наблизилися до афіксів, тобто афіксоїдів, що залежно від позиції в слові кваліфіковано як префіксоїди і суфіксоїди"18. Для визначення статусу того чи того елемента як кореневого С. Карпіловська висуває основні ознаки: „його здатність 1) займати початкову позицію в слові та сполучатися 3 іншими основами, суфіксами або флексіями; 2) сполучатися 3 префіксами та 3) в кінцевій позиції приєднуватися до початкової основи за допомогою 3'єднувального голосного"19. Однак кореневий морф може і не поєднуватися ні з суфіксом, ні з флексією, ні зі з'єднувальною голосною. Ураховуючи викладений вище матеріал і семантичні особливості чужомовних елементів у термінології, зокрема фітомеліоративній, пропонуємо так визначати їхній статус. Кореневий морф - це самостійна морфологічна одиниця чужомовного походження, носій конкретного спеціального, суто фахового значення, що домінує порівняно зі значеннями інших компонентів складної одиниці; у складному слові може бути і першою, і другою його частинами, а також поєднуватися як $з$ коренями, так і з афіксами та афіксоїдами. Афіксоїд - це чужомовний елемент, який у мові-реципієнті настільки засвоївся, що став формантом і виконує службову функцію; має ознаки повторюваності, тобто здатний поєднуватися 3 кореневими морфами й набувати узагальненого значення, властивого службовим морфемам, продукуючи спеціальні одиниці з узагальненим значенням. Залежно від позиції в спеціальному слові виділяємо префіксоїди та суфіксоїди.

У фітомеліоративній лексиці виокремлюємо такі чужомовні елементи:

1) кореневі морфи: агро- (грец. agros - поле, “агрономічний”) агробіогеоценоз, агрорайонування, агротераса, агрофітоценоз; біо- (грец. bios - життя, за значенням відповідає поняттям “біологічний” і “життя”) біогеоиеноз, біоіндикатор, біомаса, біоморфа, біосинтез, біосфера, біофільтр, біоценоз, біоценологія та ін.; гео- (грец. gе̄ - Земля, перша частина складних слів, що відповідає поняттю “земля") - геоекобіота, геоморфологія; ziдpo- (грец. hydōr - вода, вказує на зв'язок із водою, водними просторами та ін.) - гідрофіти; гігро- (грец. hygros - вологий) гігроскопічність; зоо- (грец. zōon - тварина) - зоолісомеліорація; ксено- (грец. хеnos - чужий) - ксенобіотики; ксеро- (грец. хеrōs - сухий) - ксерофіти, ксеромезофіти; мезо- (грец. mesos - середній, серединний; відповідає поняттям “середній”, “помірна величина” або “проміжне положення чого-небудь”) - мезосапроби, мезоксерофіти; фото- (грец. phōtos — "світло; той, що діє за допомогою світла") — фотосинmез; -стаз (грец. stasis - стояння, зупинення руху фізіологічного вмісту) гомеостаз; - $\boldsymbol{\text { mon }}(u)$ (грец. topos - зв'язок із поняттям "місце") - eдатоп, клімamon; -mpoф $(u)$ (грец. trophē - їжа; друга частина складних слів, що вказує на зв'язок із поняттям “живлення", “їжа”) - автотрофи; -ценоз (грец. koinos — "сукупність”) — агроценоз, акваценоз, біогеоценоз, вітоценоз, культурфітоценоз, помологоценоз, стрипоценоз, флороценоз, фрутоиеноз; -циди

${ }^{18}$ Н. С. Кобзар, Чужомовні словотвірні елементи в українській біологічній термінології, автореф. дис... канд. філол. наук, Харків 2008, с. 6.

${ }_{19} €$. А. Карпіловська, Суфіксальна підсистема сучасної украӥнської літературної мови: будова та реалізація, Київ 1999, с. 186. 
(лат. caedo - убиваю; частина складних слів, що відповідає поняттю “знищувачі”) — акарищиди, гербічиди, інсектищиди, пестициди і т. ін.;

2) префіксоїди: авто- (грец. autos - сам, має значення “свій”, “власний”, “само...") - автотрофи; інтра- (лат. intra - всередині) - інтразональність; макро- (грец. macros - довгий, великий; має значення "великий”, “довгий” або пов'язаний з вивченням чи вимірами великих предметів, величин) - макроелементи, макрорельєф, макрофактори; мега- (грец. megas великий; що відповідає поняттю “великий”, “мільйон”, “велетенський”) мегарельєф; мікро- (грец. micros - має значення "малий”, "найдрібніший”, пов'язаний із вивченням чи вимірюванням малих величин) - мікроасоціація, мікроклімат, мікрорельєф, мікрофлора; нано- (грец. nannos — карликовий) - нанорельєф;

3) суфіксоїди: -лог(ія) (грец. logos — слово, учення; розділ науки) - аутекологія, біоченологія, геоморфологія; -фаг (грец. phagos - пожирач, друга частина слів, означає “поїдач”, “поглинач”) - ентомофаг, фiтофаг; -філ(и) (грец. philos — “любитель”, “прихильник") - ефемерофіли, ащидофіли.

Зауважмо, що деякі елементи можуть бути кваліфіковані по-різному, зокрема Н. Кобзар визначає елементи дендро-, фіто- (лише в препозиції) як префіксоїди ${ }^{20}$. Однак ми вважаємо їх кореневими морфами, оскільки, напр., компонент фimo- (грец. phyton - рослина) безпосередньо вказує на зв'язок із поняттям “рослина", тобто на належність терміноодиниць до фітомеліоративної термінології. В аналізованій лексиці він уживається і в пре-, і в постпозиції. Терміни з препозитивним кореневим морфом фimo- позначають: назви сукупностей рослинних організмів (фітоценоз, фітоценопопулящія), назви сукупностей тварин (фiтофаги, фiтопаразити), назви маси всіх рослин і їхніх частин (фітомаса), назви атмосферних умов рослинного середовища (фiтоклімат), назви дій чи процесів (фітодизайн, фітоіндикаиія), назви наукових галузей (фітомеліорачія, фітоценологія) та ін. У постпозиції кореневий елемент -фіти вказує на належність до певного типу рослин (геліофіти, гелофimu, гідрофimu, ксерофіти, ксеромезофіти, мезоксерофіти, сапрофіти, склерофіти, сиіофіти, хазмофіти). Як видно з наведених прикладів, термінів з елементами фimoй -фіти у складі досліджуваної термінології значна кількість, вони виявляють високу словотвірну активність, залишаються носіями лексичного значення термінів, тому, на нашу думку, є коренями. За допомогою цих елементів утворено близько семи терміно-семантичних груп, які формують поняттєве ядро фітомеліорації. Серед аналізованих власне фітомеліоративних термінів виділяємо головний — фітомеліоращія, утворений сполученням чужомовних кореневих морфів, який позначає: 1) науку, що вивчає способи поліпшення стану земель; 2) комплекс заходів щодо поліпшення умов довкілля за допомогою культивування рослинності або підтримання фітоценозів.

У фітомеліоративній термінології спостерігаємо абсолютну перевагу словотвірних елементів грецького походження. Більшою мірою досліджувана терміносистема збагатилася чужомовними кореневими морфами (70 \% від загальної кількості чужомовних терміноелементів, використовуваних для творення фітомеліоративних термінів), меншою мірою префіксоїдами та суфіксоїдами. Кореневі запозичені елементи семантично розширюють поняттєве поле галузі; префіксоїди вказують на головну чи додат-

${ }^{20} \mathrm{H}$. С. Кобза р, Чужомовні словотвірні елементи в украйнській біологічній термінологї̈, автореф. дис... канд. філол. наук, Харків 2008, с. 7. 
Морфологічні способи термінотворення

(на матеріалі сучасної украӥнської фітомеліоративної термінологї)

кову властивість або ознаку об'єкта; суфіксоїди виконують систематизувальну функцію, тобто класифікують термінологічні одиниці.

Із урахуванням викладеного вище матеріалу висновкуємо, що морфологічне творення термінів фітомеліорації здійснюється за тими самими способами й принципами, що й словотворення загальновживаних одиниць української літературної мови (префіксальним, суфіксальним, префіксально-суфіксальним та основоскладанням). Особливістю творення фітомеліоративних термінів $\epsilon$ широке використання чужомовних елементів - як службових, так і кореневих. Для розбудови термінології фітомеліорації питомі морфеми мають більші дериваційні можливості. 